\title{
Double Food Quality: Media Coverage in the Czech Republic
}

\author{
${ }^{1}$ Miroslav Jurásek, ${ }^{2}$ Emil Velinov \\ ${ }^{1,2}$ University of Administration and Finance, Czech Republic
}

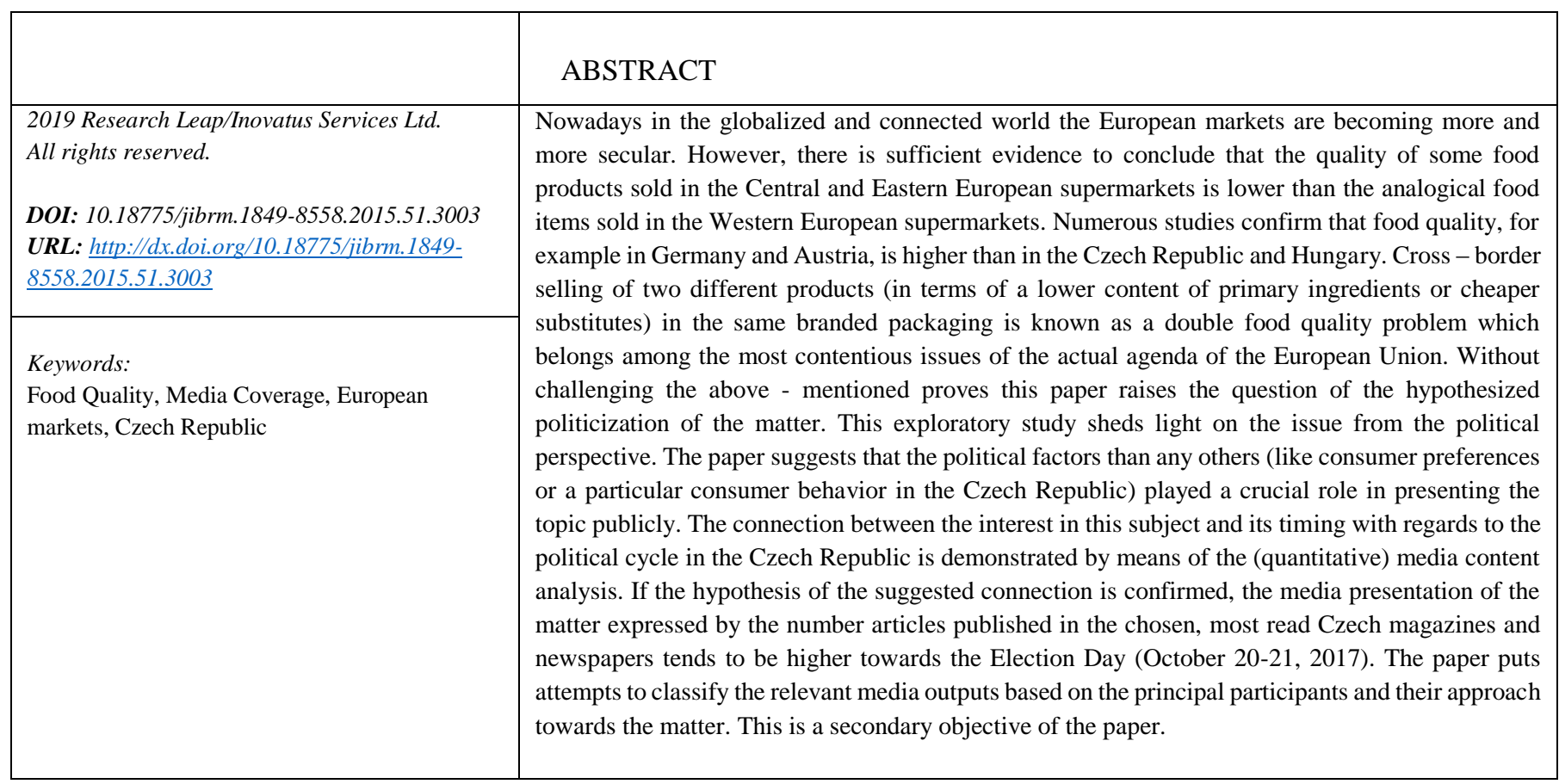

\section{Introduction}

"Different food manufacturers who were found earlier this year to be selling with a lower content of primary ingredients or cheaper substitutes in Eastern European markets" (Nováková 2017). This phenomenon has been labeled as a double food quality. The main problem of this business practice consists in presenting two different products in the same branded packaging which might be misleading and unfair to consumers. As a result the political leaders in Slovakia, the the Czech Republic, Bulgaria and Hungary, among others have been holding discussions on "food apartheid". Double standards of food quality were criticized by European Commission President Jean - Claude Juncker in his speech addressed to the European Parliament in 13 September of 2017. In his words there should be no "second class consumers" (Tamma 2017).

In 2011 the Slovak Consumer Association pointed out to the problem of double food quality for (Sehnalová 2017). Subsequently Olga Sehnalová, a Czech deputy for the Social Democratic Party (ČSSD) in the European Parliament, presented the issue in the European Parliament. It was for the first time because till that time it was 'quite uninteresting political issue here' (Sehnalová 2017).

\section{Research Objective and Research Question}

The topic on the double quality of food can be broadly defined as a 'problematic political and economic issue related to the food distribution in the Single European Market'. It is highly useful and practical to undergo this kind of the study because such a kind of business practices might be strengthening a negative perception of a 'bad' EU among Czechs and others; the issue has been solved and discussed on the ground of the European institutions (the European Commission or the European Parliament); for some European citizens the double quality of food can represent the symbol of inequality. The issue calls for the active approach of all involved.

This paper is designed as an exploratory study with the aim to find out "what is happening and to seek new insights" (Saunders 2003). Two principal ways of conducting this research were used: 1) a search of the literature (no relevant scientific article in the databases like PROQUEST has been 
found) and 2) the contact with experts, particularly with a Billa manager who provided confidential data of internal researches. The paper has an objective: to analyze the media coverage of the double food quality issue. Because the media setting undoubtedly influences the public opinion and the behavior of people (McCombs and Reynolds 2002), the media coverage reveals the interest in the issue among the Czech population. If the topic is largely covered by the Czech media, it can have impact on the attitudes towards the European Union. The question is whether or not the issue was used (except for other motives) by the (Eurosceptic) political parties in the election run-off 2017. Does the timeline distribution of the articles in the Czech printed newspapers and magazines imply any connection between the topic (and its 'attractiveness' among some Czech citizens) and the fight for voters?

To answer this question two variables were identified and determined: the independent is the timeline of the political cycle in the Czech Republic; in the studied period (see chapter 3.6) the elections were held in 2013 and 2017. In accordance with the theory of political cycle (see for example Dubois 2016; Martínez 2009) the presentation of this popular topic (as a dependent variable) in the Czech media should be intensified in the time period around the Election Day 2017. The Figure 1 depicts variables and it shows the model, on which is based the quantitative analysis. The independent variable (the year of a political cycle in the Czech Republic) influences the single dependent variable - a perception of the importance of the studied topic expressed by its reflection in the Czech printed media. The following hypothetical statement is tested: the number of published articles tends to be higher around the election year 2017; the correlation between the election year 2017 and the number of published articles is supposedly positive: it is expected the highest number of published articles in 2017. This positive correlation is depicted by the symbol ' + ' in the diagram. Since an 'affair' of double quality of food in the European Parliament dates back to 2011 (Sehnalová 2017), a 'control' election year 2013 (plus one year more, 2012, of the previous political cycle) was included in the study.

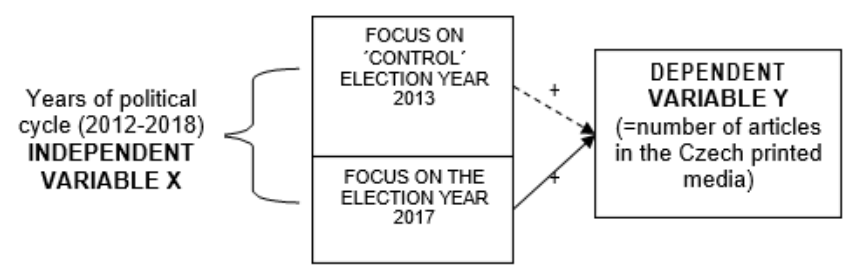

Figure 1: One independent variable $\mathrm{X}$ influences dependent variable $\mathrm{Y}$

\section{Research Strategy}

\subsection{The Philosophical Worldview Proposed in the Study}

The term worldview means "a basic set of beliefs that guide action" (Creswell 2008). A research strategy in this paper is framed by the postpositivist worldview which holds a deterministic philosophy in which causes probably determine effects or outcomes. It is well-known that the knowledge developed through a postpositivist lens is based on observation and measurement of the objective reality that exists out there in the world. In accordance with the postpositivist worldview the quantitative research is carried out in this paper.

The chosen research strategy based on the postpositivist worldview has the following consequences (Creswell 2008): 1) absolute truth can never be found which implies that gathered evidence is always imperfect and fallible, 2) data, evidence, and rational considerations shape knowledge, 3) there are developed relevant, true statements, ones that can serve to explain the situation of concern. The postpositivist worldview is mainly connected with the quantitative research methodology.

\subsection{The Review of Literature}

'Double quality of food' became a major road sign, a tangible idea in not only business research, but also in a research of the political negotiation process. Because the topic is relatively new and fresh, no scientific journal articles or academic monographs cover the subject of double food quality. Of course, many highly specialized studies aiming at the comparison of the quality of food distributed in the supermarkets across the EU countries have been conducted till nowadays (Klánová 2017). Furthermore, the issue has been broadly discussed in the Czech Republic. Many thematic conferences, in which experts, politicians, academics and representatives of the professional associations (like the Czech Confederation of Commerce and Tourism) participated, were held. The topic is very well described and documented in the media.

\subsection{Used Methods}

This paper uses mixed methods research (the combination of quantitative and qualitative approaches) that has gained popularity recently (Creswell 2009). Mixed methods utilize the strengths of both qualitative and quantitative research. There is more insight to be gained from the combination of both qualitative and quantitative research than either form by itself. For the examination of the media coverage in the Czech Republic was chosen a method of media (quantitative) content analysis which may be briefly defined as "the systemic, objective, quantitative analysis of message characteristics" (Neuendorf 2002). The chosen method fits the positivism paradigm of social research and accomplishes all criteria of the scientific method: objectivity, reliability, validity, generalizability, replicability (Grunert 2005).

The next complementary (qualitative) exploration of the media articles (see 3.6) in the period from October, 2017 to present made possible to identify 5 principle agents connected with the issue of double quality of food (see Figure 2). 
This qualitative analysis categorized five principal actors (or agents) engaged in the issue: 1) Professional Associations: i.e. The Association of Consumers - in the Czech Republic or in the Slovak Republic; institutions, academic centers or organizations that have conducted the surveys on the quality of food or they are somehow involved in the activities of food industry such as 'Potravinářská komora ČR') fit this category as well; 2) policymakers: this category involves the local, regional, national (ministers, presidents), cross-national politicians (for instance, the Czech deputy in the European Parliament Olga Sehnalová or Věra Jourová from the Czech Republic, the European Commissioner for Justice, Consumers and Gender Equality); 3) producers or distributers of food products such as the cross-national supermarket chains Billa, Lidl, Tesco and so on; 4) consumers or citizens; 5) officials, bureaucrats: for example the representatives of the European Commission or employees of the Czech Ministry of Agriculture.

\subsection{Units of Analysis}

A unit is an identifiable message or message component, 1) which serves as the basis for identifying the population and drawing a sample, 2) on which variables are measured, or 3) which serves as the basis for reporting analyses. In this paper units of analysis (or units of sampling) are identified with the key word 'double quality food'. This problematic issue affects the EU member states. It extends across the countries such as Germany, France, the Czech Republic, the Slovak Republic and others). It symbolizes the implicit and deeply rooted controversy between 'hard-core' Europe and new EU entrants in 2004. Nevertheless, this analyses deals just with the respective situation in the Czech Republic. Because a small portion of the analyzed articles didn't concern the food quality problem in the defined perspective, they had to be excluded from the study.

\subsection{Archives}

An archive is a collection of message, usually well indexed which is to be distinguished from the index itself, which simply lists the titles and/or other identifying information about the messages. An archive contains the messages in their entireties. The databases are meant by the archives.

Nowadays, we are living in the digital age which has fundamentally changed the ways in which content analysis may be conducted. Digital technologies continue to change a number of tasks important to content analysis: archiving messages, searching for messages, preparation of messages for coding and message handling during coding, 'automatic' content analysis coding. In this paper the media content analysis is carried out with the help of the online product of Monitora, a Czech firm which specializes in the monitoring online, print and audiovisual media cover.

Monitora facilitates to track all important print and online media, and radio and television broadcast daily. It offers advanced search. Monitora works with all prominent publishers in the Czech Republic and monitors over 2000 magazines, daily magazines and periodicals, and over 4000 online sites (Monitora 2018). Monitora makes possible not only to track the number of articles, but to measure their media reach. The analytical tool developed by Monitora combines news into events and monitors their development over time. The Monitora application has been used by leading companies in the Czech Republic to monitor and analyze the media.

\subsection{Sampling}

All pieces of information covering the keyword 'double quality food' written in the Czech language were collected by the search engine, marketing tool (see 3.5) of media.monitora.cz. A sampling framework was limited by two criteria: the time (from January 1, 2012 to present) and the type of media - print. The recent data of the research 'Media Project' (Unie vydavatelů et al. 2017) has been used with the express purpose of determining a sampling framework. The selection of the print titles was guided by the intention to achieve as the high GRPs score as possible or in other words, to ensure the maximum media coverage of the topic in the Czech population (15 and more years old). In that case the impact on them would be the strongest. The analyzed media were divided in three groups: 1) weekly newspapers dealing with business and financial issues: Ekonom, Euro, 2) major national newspapers: Blesk, MF Dnes, Právo, Lidové noviny, Hospodářské noviny and 3) major national magazines: Týdeník květy, Reflex, Téma, Respekt, Týden.

\subsection{Measurement}

All units of analysis were counted and expressed by the number (this is dependent variable). Moreover, the attention was also paid to the timeline of the publication which could have a political connection with some important events either in the Czech Republic or EU (the date of publishing as independent variable). Besides, the measures of Gross Rating Points (GRPs) and Oportunity to See (OTS) were presented.

Gross rating point does not measure the size of the audience reached; rather, GRPs quantify impressions as a percentage of the target population. One gross rating point corresponds to one percent of the whole Czech population $15+$ years old. GRPs are used as a measure of media with high potential exposures or impressions, it means to measure impressions to the number of people in the target. GRPs are total impressions related to the size of the target population. In this sense, GRPs is an appropriate concept than a mere number of published articles because it provides a better media image of a given topic.

OTS is a related measure and shows how many times had an individual in a target group to read on average an article. For all the population $15+$ OTS $=$ GRP $/ 100$. 


\section{Data Presentations}

The table 1 examines the media sampling data (see chapter 3.6) from January 1, 2012 to March 12, 2018. 114 articles were published in the defined newspapers and magazines (see chapter 3.6). The most articles were published in years 2017, 2018. Most articles in the defined media ( 6 articles) came out in September 14, 2017 which is due to the media coverage of Juncker's annual speech on the State of the Union 2017 delivered a day before (September 13). On this occasion the European Commission President was speaking about the matter of dual quality of food and the necessity to solve the problem. It is logical that the measures like GPR's and OTS's must reach the highest rates in 2017. The print media have been chosen in order to cover $80 \%$ of the Czech population (all inhabitants $15+$ years old); if OTS equals to 1.92 in 2017 , it means that the target audience ( $80 \%$ of the Czech population) read (registered) the articles on double food quality almost twice. Of course, it is dubious whether this frequency is efficient enough to influence and affect the decision process in regard to the Czech parliamentary elections or the Czech antipathies to the European Union.

Table 1: Print media outputs January 1, 2012 - March 12, 2018(author's elaboration from monitora 2018)

\begin{tabular}{|c|c|c|c|c|c|c|c|}
\hline YEAR & 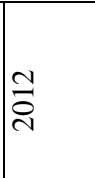 & $\stackrel{m}{\stackrel{2}{\circ}}$ & $\stackrel{\Delta}{\stackrel{d}{\circ}}$ & $\frac{n}{2}$ & $\stackrel{0}{\stackrel{2}{c}}$ & $\stackrel{ }{\circ}$ & $\stackrel{\infty}{\stackrel{i}{\sim}}$ \\
\hline $\begin{array}{l}\text { Number of } \\
\text { published } \\
\text { articles }\end{array}$ & 2 & 3 & 8 & 3 & 8 & 79 & $\begin{array}{l}1 \\
1\end{array}$ \\
\hline $\begin{array}{l}\text { The } \\
\text { highest } \\
\text { number of } \\
\text { published } \\
\text { articles - } \\
\text { title }(\%)\end{array}$ & $\begin{array}{l}\text { Ekon } \\
\text { om } \\
(100 \\
\%)\end{array}$ & $\begin{array}{l}\text { Tý } \\
\text { den } \\
(33 \\
, 3 \\
\%)\end{array}$ & $\begin{array}{l}\text { Pr } \\
\text { ávo } \\
(62 \\
, 5 \\
\%)\end{array}$ & $\begin{array}{c}\text { Respe } \\
\text { kt, } \\
\text { Právo, } \\
\text { HN } \\
(33,3 \\
\%)\end{array}$ & $\begin{array}{c}\text { Práv } \\
\text { o, } \\
\text { Euro, } \\
\text { HN } \\
(25 \% \\
)\end{array}$ & $\begin{array}{l}\text { Pr } \\
\text { ávo } \\
(41, \\
4 \%)\end{array}$ & $\begin{array}{l}\text { Prá } \\
\text { vo } \\
(36, \\
4 \%)\end{array}$ \\
\hline GPR & 1,27 & 1,65 & 20,79 & 6,46 & 12,16 & $\begin{array}{c}191 \\
60\end{array}$ & $\begin{array}{l}24 \\
52\end{array}$ \\
\hline OTS & 0,01 & 0,02 & 0,21 & 0,06 & 0,12 & 1,92 & $\begin{array}{c}0,2 \\
5 \\
\end{array}$ \\
\hline
\end{tabular}

\section{Data Analysis and Interpretation}

\subsection{The Quantitative Approach}

The topic 'double quality of food' drew the most attention in 2017 and partly in the ongoing year 2018. Only a relatively low number of articles concerning the topic were published in other years. Some of these articles (being out of the research topic) have been excluded. The parliamentary (general) elections were held in the Czech Republic in 2017 and this fact may explain the highest number of the published articles about double food standard. It is easily understandable that this topic resonates especially among Czechs who have a eurosceptic stance of the Czech membership in the EU (Kovár 2018).
The political movement ANO led by a billionaire Andrej Babiš won the election in the end. Věra Jourová as a European Commissioner is responsible for a protection of consumers in the European Single Market. Jourová as a ANO's nominee for the Commissioner was 'visible' (see Čermáková and Štechová 2018) in the Czech media in time around the Election Day: 7 articles (searched out by media.monitora.cz on the base of the keywords Jourová, double food quality) were published in the selected print media in September and October 2017. The issue could have been positively connected with the name of Jourová and unconsciously with the movement ANO.

Last, but not least one more interesting finding can be mentioned. Most articles were published by Právo that is the only Czech national daily newspapers not owned by a foreign company. Právo is not directly linked to any political party, but is ideologically close to the Czech Social Democratic Party. It maintains a left-wing stance and the focus on social issues.

\subsection{The Qualitative Approach}

A total of 114 articles concerning the double food quality issue were identified. A part of these articles (dated from September 2017 to March 2018) was analyzed qualitatively with the purpose of determining the principal agents engaged in the issue. The figure 2 shows the results of this analysis. Although magazines and newspapers of the economical specialization were included, most published articles tackled the problem from the political point of view.

The conducted analysis has revealed two main perspectives: internal (Czech one) and external (i.e. the handling of the problem by the European institutions like the European Commission or Parliament or by the foreign countries). Five principal actors were identified: policymakers, professional associations, consumers, producers and officials/bureaucrats (such as officials of the Ministry of Agriculture and others). The Czech print media stressed mostly the political side of the issue, which is not surprising.

\section{Discussion}

The issue of double food quality deserves the continued attention. This paper focused on the quantitative analysis of the topic perception in the Czech print media. Of course, the analogical analysis of other media types (TV, radio, internet) could have completed the media image of the issue.

The interest in the issue can be seen not only in the Czech Republic, but also in other former communist countries like Poland, Hungary, the Slovak Republic or Bulgaria. For example, the survey (Ministry of Agriculture Press Office 2017) ordered by Sándor Fazekas, Hungarian minister of Agriculture, found differences in composition of ingredients or sensory perception in one third of products tested. This proves that the existence of double standards in the quality of food exists in the European Union. 
This paper presents a single case study focusing on the situation in the Czech Republic. It is useful to carry out the (similar) comparative analysis in other affected countries (like the Slovak Republic, Hungary, Poland or Bulgaria). This comparative analysis could have answered the paper hypothesis whether or not the issue was medialized just for the political purposes (in connection with the political cycle and the ambition of politicians to show off as the 'right fighters' for the national interests to their electorate).

If this hypothesis confirmed, then the international management strategy can come to a discussion. For instance, it is possible to examine the business motivation for the different packaging of the identical products distributed in various European countries. Does this strategy have anything to do with the different consumer preferences or is this strategy conditioned by the cultural differences between various states? These might be questions for the future research.

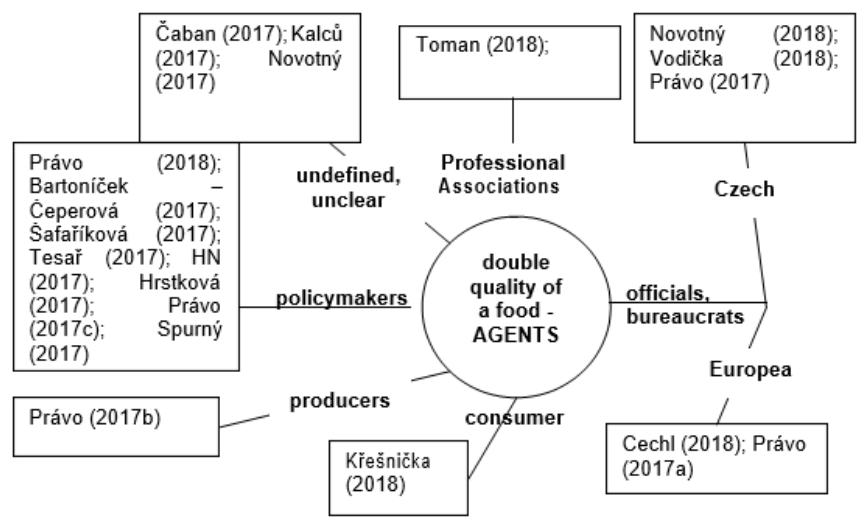

Figure 2: Qualitative analysis of selected articles

\section{Conclusion}

So-called "dual-quality foods" have been on Central European governments' radar for years, but Slovakia's presidency of the Council of the European Union has brought their hopes that Bratislava will finally push to battle double standards by launching programs toward tighter regulation at the European level. The Slovaks, strongly supported by the Czechs, are putting efforts to rectify what they see as an unfair distortion of the single market.

The presented exploratory study is seeking new insights to assess the phenomenon of the widespread problem in the EU double food quality. The topic was studied with the help of the media content analysis. Five principal actors connected with the matter were identified; this opens new horizons for the future research: it is possible to examine and asses the role of these actors in the matter.

This paper points to the presentation of the topic in the Czech media assuming a higher interest in the agenda of double food quality in the years around the Parliamentary elections (years 2013, 2017). The perception of this problem from the perspective of Czech consumers (=voters) was measured by the number of published articles in the Czech most bought and read newspapers and magazines (the next research could concentrate on the study of other media types - TV, radio, online).

The authors of the paper found out that the most articles had been published in 2017 (the election year) which could have confirmed the hypothesis: double food standard issue was politicized in the Czech Republic to some extent; perhaps this finding is rather trivial and not surprising, on the other side the issue is not new at all and it could have been discussed in the Czech media earlier. But this didn't happen as the paper demonstrated. This conclusion resonates with the appeal of Marta Nováková, the President of the Czech Confederation of Commerce and Tourism, to postpone discussion on the matter when the election run-off is over (SOCR 2017).

\section{References:}

- Adámková, Alena (2017), "Rozdílná kvalita potravin”, in Retail News (4/ 2017), 24-25.

- Bartoníček, Radek, Klára Čepelová (2017), “Češka mezi nejlepšími Evropany”, in Právo (Decembre 11, 2017), 4.

- Cechl, Pavel (2018), "Lancheon Meat jako z Německa", in Týden (February 5, 2018), 10-11.

- Creswell, John (2008), Research Designs: Qualitative, Quantitative, and Mixed Methods Approaches (3rd Edition), Sage Publications, Inc.

- Čaban, Martin (2017), "Doba návratů”, in Reflex (Novembre 9, 2017), 18.

- Čermáková, Eva, Věra Štechová (2018) ), “Jourová chce, aby se dvojí kvalita potravin stala nekalou praktikou. V dubnu to navrhne Evropské komisi“" (accessed March 11, 2018), [available at https://www.irozhlas.cz/].

- ČTK (2011), "Do postkomunistických zemí se dovážejí horší potraviny než na Západ“(accessed March 11, 2018), [available at https://ekonomika.idnes.cz/].

- Dimara, E., \& Skuras, D. (2005), “Consumer demand for informative labeling of quality food and drink products: a European Union case study", in Journal of consumer marketing, 22(2), 90-100. Crossref

- Doboi, Eric (2016), "Political business cycles 40 years after Nordhaus," in Public Choice, 166 (1-2), 235-259. Crossref

- Grunert, Klaus G. (2005), "Food quality and safety: consumer perception and demand," in European review of agricultural economics, 32(3), 369-391. Crossref

- HN (2017), "Češka mezi nejvyspělejšími Evropany”, in Hospodářské noviny (Decembre 11, 2017), 1. HN (2017a), "Západní Balkán by měl jít rychleji do Evropské unie", in HN (Octobre 16, 2017), 3.

- Hrstková, Julie (2017) “Jsme to, co jíme, lidé dvojí kvality”, in HN (Octobre 16, 2017), 8.

- Kalců, David (2017), "Kterak vést boj proti dvojí kvalitě potravin”, in Květy (Octobre 26, 2017), 14. Klánová, Eva (2017), "Př́iběhy naruby", in Retail News (7-8/ 2017), 15. 
- Kovár, Jan (2018), "Euroscepticism is on the Rise in the Czech Republic" (accessed March 28, 2018), [http://emerging-europe.com/voices].

- Křešnička, Jakub (2018), "Stát chystá hromadné žaloby po vzoru USA", in Týden (February 26, 2018) m 48.

- Martínez, Leonardo (2009), "A Theory of Political Cycles," in Journal of Economic Theory (144/3), 1166- 1186. Crossref

- McCombs, Maxwell, and Reynolds, Amy (2002), "News Influence on our picture of the world," in Media Effects Advances in Theory and Research, Jennings Bryant and Dolf Zillmann, eds. New Jersey, Lawrence Erlbaum Associates, Inc., Publishers, 1-19.

- Ministry of Agriculture Press Office (2017), "Dual Quality also Apparent with relation to 'Summer products", (accessed March 28, 2018), [http://www.kormany.hu/en/ministry-ofagriculture/news/double-standards-also-traceable-in-caseof-summer-products].

- Monitora (2018), "We are the leader in the number of monitored titles" (accessed March 31, 2018), [https://monitora.cz/en].

- Neuendorf, Kimberly A. (2002), the Content Analysis Guidebook. Thousand Oaks: Sage Publications, Inc.

- Nováková, Marta (2017), "Marta Nováková vystoupila v Evropském parlamentu na veřejném slyšení $\mathrm{k}$ rozdílné kvalitě výrobků" (accessed March 27, 2018), [http://www.socr.cz/]

- Novotný, Jiří (2018), "V obchodech má být povinné české zboží”, in Právo (March 2, 2018), 17. Novotný, Jiří (2017), "Žofínské fórum se bilo za české potraviny", in Právo (Octobre 4, 2017), 3. Pokorný, Pavel (2011), "Není cola jako cola. Jsme spotřebitelé druhé kategorie? "(accessed March 3, 2018), [http://ceskapozice.lidovky.cz].

- Právo (2018), "Babiš je pro vstup Bulharska do Schengenu", in Právo (January 23, 2018), 15.

- Právo (2017), "Rozdílnou kvalitu stejných potravin by mohl omezit elektronický registr”, in Právo (Decembre 11, 2017), 19.

- Právo (2017a), "Brusel Praze: Ǩecký jogurt jen z Řecka", in Právo (Novembre 15, 2017), 13.

- Právo (2017b), "Dvojí kvalita v naší firmě neexistuje, stejné označené výrobky máme pro celý svět", in Právo (Novembre 11, 2017), 17.

- Právo (2017c), "Sobotka žádá brzdu nekalých praktik", in Právo (Octobre 14, 2017), 16. Právo (2017d), "Češi mají v pizze tuk místo sýru”, in Právo (Octobre 13, 2017), 8.

- Tamma, Paola (2017), “'No Second Class Consumers': Juncker Slams Double Food Quality in the EU" (accessed March 3, 2018), [available at https://www.euractiv.com].
- Tesař, Milan (2017), "Božská komedie české politiky", in Reflex (Octobre 19, 2017), 12, 14.

- Saunders, Mark et al. (2003), Research Methods for Business Students (3rd Edition), Harlow: Pearson Education Limited.

- Sehnalová, Olga (2017), "Dvojí kvalita jako symbol dvojího metru" (accessed March 11, 2018), [available at https://www.cssd.cz/aktualne/blogy/dvoji-kvalita-jakosymbol-dvojiho-metru/].

- Šafaříková, Kateřina (2017), "Macron má střední Evropu skutečně rád", in Respekt (Novembre 20, 2017), 45-48.

- SOCR (2017), "Stanovisko SOCR ČR k tzv. dvojí kvalitě potravin - tisková zpráva" (accessed March 3, 2018), [available

at http://www.socr.cz/file/4110/TP_SOCR_dvoji_\%20kvalita .pdf].

- Špačková, Iva - Kunc, Tomáš (2017), “České, regionální či bio? Průzkum ukázal, na co Češi nejvíc slyší při nakupování“(accessed March 3, 2018), [available at https://zpravy.aktualne.cz/].

- Spurný, Jaroslav (2014), "Chceme být jako CDU", in Respekt (Octobre 2, 2017), 30-31.

- Toman, Miroslav (2018), "Události“", in Hospodářské noviny (February 28, 2018), 5.

- Unie vydavatelů et al (2017), "Media projekt 1.1.-17.12. 2017" (accessed March 3, 2018), [available at http://www.unievydavatelu.cz/cs/unie_vydavatelu/medialn i_data/vyzkum_ctenosti].

- Vodička, Viktor (2018), "Česko povolí hromadné žaloby", in Hospodářské noviny (February 26, 2018), 1. 